\title{
Hippocampal Synaptic Plasticity in Mice Overexpressing an Embryonic Subunit of the NMDA Receptor
}

\author{
Shigeo Okabe, ${ }^{1}$ Carlos Collin, ${ }^{1}$ Jonathan M. Auerbach, ${ }^{1}$ Noam Meiri, ${ }^{2}$ Johan Bengzon, ${ }^{1}$ Mary B. Kennedy, ${ }^{3}$ \\ Menahem Segal, ${ }^{4}$ and Ronald D. G. McKay ${ }^{1}$ \\ ${ }^{1}$ Laboratory of Molecular Biology and 2Laboratory of Adaptive Systems, National Institute of Neurological Disorders and \\ Stroke, National Institutes of Health, Bethesda, Maryland 20892, 'Bivision of Biology, California Institute of Technology, \\ Pasadena, California 91125, and ${ }^{4}$ Department of Neurobiology, The Weizmann Institute of Science, Rehovot 76100, Israel
}

The effects of changing NMDA receptor subunit composition on synaptic plasticity in the hippocampus were analyzed by creating transgenic mice overexpressing NR2D, a predominantly embryonic NMDA receptor subunit. NMDA-evoked currents in the transgenic mice had smaller amplitudes and slower kinetics. The transgenics also displayed age-dependent deficits in synaptic plasticity in area CA1 of the hippocampus. Long-term depression was selectively impaired in juvenile mice when NR2D overexpression was moderate. In mature mice, overexpression of NR2D was associated with a reduction of both
NR2B and $\mathrm{Ca}^{2+}$-independent activity of $\mathrm{Ca}^{2+}$ - and calmodulin-dependent protein kinase II. These biochemical changes were correlated with a marked impairment of NMDAdependent long-term potentiation, but spatial behavior was normal in these mice. These results show that the developmental regulation of NMDA receptor subunit composition alters the frequency at which modification of synaptic responses occur after afferent stimulation.

Key words: hippocampus; NMDA receptor; long-term potentiation; long-term depression; water maze; transgenic mice
Long-term potentiation (LTP) and long-term depression (LTD) are two forms of plasticity that have been studied extensively in area CA1 of the hippocampus. Both LTP and LTD, triggered by either high-frequency stimulation (HFS) or low-frequency stimulation (LFS) of the Schaffer collateral CA1 synapses, involve calcium influx through NMDA receptors (Collingridge et al., 1983; Dudek and Bear, 1992; Mulkey and Malenka, 1992). A recent analysis of mice genetically modified to express higher levels of the $\mathrm{Ca}^{2+}$-independent form of $\mathrm{Ca}^{2+}$ - and calmodulindependent protein kinase $\mathrm{II} \alpha(\mathrm{CaMKII} \alpha)$ suggests that the threshold of stimulus frequency required to elicit an increase or decrease of synaptic strength can be modulated by the amount of $\mathrm{Ca}^{2+}$-independent activity of CaMKII (Mayford et al., 1995). This work provides evidence that LTP and LTD share the same downstream pathway from the NMDA receptor activation and that CaMKII is one of the regulators of the Hebbian synaptic modification. A theoretical study has pointed out that the $\mathrm{Ca}^{2+}$ increase in the postsynaptic site after HFS can be altered dramatically by several factors, including NMDA receptor channel kinetics (Gold and Bear, 1994). This model predicts that a change in the decay constant of NMDA receptor channels of $100 \mathrm{msec}$ can induce a 10 -fold difference in the peak $\mathrm{Ca}^{2+}$ concentration in

Received Jan. 20, 1998; revised March 9, 1998; accepted March 13, 1998.

J.M.A. was supported by a Human Frontier Science Program Long-Term Fellowship. We thank Drs. M. Mayford and E. R. Kandel for the CaMK promoter, Drs. P. Seeburg and M. Hollmann for NMDA receptor cDNAs, Drs. R. J. Wenthold, B. Wolfe, M. Sheng, and A. Czernik for antibodies, and Drs. C. J. McBain and M. L. Mayer for valuable comments on this manuscript.

Correspondence should be addressed to Ronald D. G. McKay, National Institutes of Health, National Institute of Neurological Diseases and Stroke, Laboratory of Molecular Biology, Building 36, Room 5A29, 36 Convent Drive-MSC 4092, Bethesda, MD 20892-4092.

Dr. Okabe's present address: National Institute of Bioscience and Human Technology, Tsukuba, Ibaraki 305, Japan.

Dr. Bengzon's present address: Restorative Neurology Unit, University Hospital, Lund S-22185, Sweden.

Copyright (C) 1998 Society for Neuroscience $\quad 0270-6474 / 98 / 184177-12 \$ 05.00 / 0$ the dendritic spine. Thus, modulation of NMDA receptor properties might also be an efficient site for the frequency-dependent regulation of synaptic modification.

The NMDA receptors in the brain are complexes of NR1 and NR2 subunits (Sheng et al., 1994). The NR1 subunit is essential for NMDA receptor function and is expressed ubiquitously in the brain (Moriyoshi et al., 1991; Flint et al., 1997). In contrast, NR2A-D subunits have distinct expression profiles that are regulated both developmentally and regionally (Kutsuwada et al., 1992; Watanabe et al., 1992; Monyer et al., 1994). The duration of NMDA receptor-mediated excitatory postsynaptic currents becomes progressively shorter in parallel with the upregulation of the NR2A subunit in the rat cortex (Carmignoto and Vicini, 1992; Sheng et al., 1994). These data raise the possibility that NR2 subunits regulate synaptic plasticity. In this sense, analysis of the synaptic plasticity of neurons containing the NR2D subunits is intriguing because the NR2D subunit forms channels that have much longer deactivation time and lower NMDA-mediated currents in a heterologous expression system (Monyer et al., 1994). NR2D is abundant in the embryonic CNS and abruptly lost in the postnatal forebrain (Watanabe et al., 1992; Monyer et al., 1994). To define the effects of inserting the NR2D subunit into the NMDA receptor complex, we made transgenic mice overexpressing NR2D in mature forebrain. CA1 pyramidal neurons of transgenic mice showed NMDA-dependent currents that were slower and smaller than in controls. In transgenic animals, Schaffer collateral CA1 synapses showed age-dependent impairment of LTP and LTD. There were no deficits in spatial memory tasks in transgenic mice.

\section{MATERIALS AND METHODS}

Generation of transgenic mice. An $8.5 \mathrm{~kb}$ upstream region of the $\mathrm{CaMKII} \alpha$ gene was replaced with cytomegalovirus (CMV) promoter of pCMV $\beta$ vector (Clontech, Cambridge, UK), and the rat cDNA of NMDAR2D was subcloned into the NotI site of this plasmid. The insert 
was purified by sucrose density gradient and injected into the pronucleus of fertilized eggs. Hybrids of $\mathrm{C} 57 \mathrm{Bl} / 6$ and $\mathrm{C} 3 \mathrm{H}$ (B6C3) were used as hosts of transgene and were backcrossed six to seven times onto C57Bl/6 background. Lines 9 and 17 were used primarily in this study. Basically identical results were obtained with these two lines, and data from line 9 were presented except where noted. The genetic contribution of $\mathrm{C} 57 \mathrm{Bl} / 6$ and $\mathrm{C} 3 \mathrm{H}$ strains at the generation when the transgenic mice were analyzed was 1.6 and $98.4 \%$ for line 9 , respectively, and 0.8 and $99.2 \%$ for line 17 , respectively. Control wild-type mice were chosen from the same littermates. For the electrophysiology of adult hippocampus and behavioral experiments, the same groups of mice were used. For the electrophysiology of juvenile hippocampus, separate groups of mice were used. Transgenic mice were screened by Southern blot analysis or PCR. For electrophysiological and behavioral studies, only male mice were used.

In situ hybridization.In situ hybridization was done on cryostat sections using ${ }^{35}$ S-labeled cRNA probes complementary to SV40 polyadenylation signal (130 bases), NR2D (361 bases), and NR2B (827 bases) sequences. $\mathrm{X}$-ray films were exposed for $2 \mathrm{~d}$.

Immunoblotting and immunoprecipitation. Protein extracts were made in the presence of phosphatase inhibitor $\left(20 \mathrm{mM} \mathrm{Na}_{4} \mathrm{P}_{2} \mathrm{O}_{7}\right)$. The samples were resolved on a $7.5 \%$ SDS-polyacrylamide gel followed by immunoblotting with monoclonal anti-NR1 (PharMingen, San Diego, CA), polyclonal anti-NR2A and -NR2B, monoclonal anti-CaMKII $\alpha$ (Life Technologies, Gaithersburg, MD), monoclonal anti-autophosphorylated CaMKII $\alpha$ (22B1), and polyclonal anti-GluR1, detected by peroxidaselabeled secondary antibodies and the ECL detection system (Amersham, Arlington Heights, IL). The films were quantitated by a densitometer.

For the quantitative analysis of NR2B and phosphorylated CaMKII, different amounts of brain extract from one wild-type mouse were blotted together with the samples to be analyzed. The standard curve showing the relationship between the amount of antigen and the density of the reactive bands on the film was made for each experiment, and the relative amount of either NR2B or phosphorylated CaMKII against the control sample was calculated.

Immunoprecipitation was done according to the method of extraction of synaptosomal preparation with sodium deoxycholate (Brahos and Wenthold, 1996). The precipitates were analyzed by immunoblotting.

Histochemical and immunocytochemical procedures. Fifty micrometer vibratome sections were stained with $2 \%$ toluidine blue or anti-calbindin (Sigma, St. Louis, MO). Primary antibody was detected by a fluoresceinlabeled secondary antibody (Cappel, Cochranville, PA). For cytochrome oxidase staining, flattened cortex was frozen, and $50 \mu \mathrm{m}$ sections were cut by cryostat. Sections were incubated with a solution containing $3 \mathrm{mg}$ of cytochrome C, $5 \mathrm{mg}$ of 3,3'-diaminobenzidine in $10 \mathrm{ml}$ of $50 \mathrm{~mm}$ phosphate buffer, $\mathrm{pH} 7.4$, at $37^{\circ} \mathrm{C}$ for several hours until good contrast was obtained.

Electrophysiological procedures. For patch-clamp experiments, coronal slices $(300 \mu \mathrm{mm})$ were prepared from rapidly decapitated mice $(10-12$ weeks old) and cut in ice-cold medium using a microslicer (Dosaka $3000 \mathrm{~W}$ ). After cutting, the slices were incubated for $30 \mathrm{~min}$ in a recovery chamber at $35^{\circ} \mathrm{C}$ and then held at room temperature until used. The holding chamber was filled with $10 \mathrm{ml}$ of artificial CSF (ACSF) containing (in mM): $124 \mathrm{NaCl}, 4 \mathrm{KCl}, 26 \mathrm{NaHCO}_{3}, 1.25 \mathrm{NaH}_{2} \mathrm{PO}_{4}, 2 \mathrm{CaCl}_{2}, 2$ $\mathrm{MgSO}_{4}$, and 10 glucose, $\mathrm{pH}$ 7.35. The ACSF was saturated with a $95 \%$ $\mathrm{O}_{2}-5 \% \mathrm{CO}_{2}$ gas mixture. Experiments were performed at $30-32^{\circ} \mathrm{C}$ with constant superfusion. Cells in hippocampal area CA1 were visualized using infrared differential interference contrast microscopy (IR-DIC) on an upright microscope (Zeiss Axioskop FS) fitted with a $40 \times / 0.80 \mathrm{~W}$ objective (Olympus, Tokyo, Japan). Slicing and recording methods were adapted from those of Stuart et al. (1993). Patch pipettes were prepared from borosilicate glass (Sutter Instruments) and filled with (in mM): 120 $\mathrm{KCl}, 2 \mathrm{Mg}$-ATP, $10 \mathrm{Na}_{2}$ phosphocreatine, 0.2 EGTA, 0.3 GTP-Tris, and 10 HEPES, pH 7.2, 320 mOsm. Cells were recorded in voltage-clamp mode. NMDA currents were evoked by puffing $10 \mathrm{~mm}$ NMDA through a patch pipette placed in stratum radiatum of CA1 on the apical dendrites of the cell being recorded using a Picospritzer (General Valve, Fairfield, NJ). Signals were amplified using an Axopatch 200B amplifier, and data were acquired and analyzed on a personal computer using pClamp 6 (Axon Instruments). TTX (1 $\mu \mathrm{mm})$ was added to the superfusion medium during recording.

For extracellular recordings the mouse was rapidly decapitated, and its hippocampus was cut on a McIlwein tissue slicer in $350 \mu \mathrm{m}$ transverse slices. The slices were incubated for $1-2 \mathrm{hr}$ in a recreation chamber at room temperature. They were transferred to the submerged recording chamber, where they were superfused with ACSF at $32^{\circ} \mathrm{C}$. The medium contained (in mM): $130 \mathrm{NaCl}, 2.5 \mathrm{KCl}, 2 \mathrm{CaC}_{2}, 1.5 \mathrm{MgCl}_{2}, 1.25$
$\mathrm{NaH}_{2} \mathrm{PO}_{4}$, and $26 \mathrm{NaHCO}_{3}$. The medium was buffered to $\mathrm{pH} 7.4$ and saturated with a $95 \% \mathrm{O}_{2}-5 \% \mathrm{CO}_{2}$ gas mixture. Bipolar stimulating electrodes were placed in stratum radiatum, near region $\mathrm{CA} 3$, and stimulated once per minute. Recording electrodes containing ACSF were placed in stratum radiatum. The slopes of the population EPSPs were recorded and averaged. The experiments were conducted in a double-blind procedure.

Open field and rotary rod analysis. The exploratory and motor behavior was determined using both an open field (a square box $50 \times 100 \times 40 \mathrm{~cm}$ divided graphically into 16 equal areas) and an accelerating rotary rod (Ugo Basile model 7650; acceleration from 4 to $40 \mathrm{rpm}$ in $5 \mathrm{~min}$ ). Ten line 9 transgenic mice and 10 wild-type mice from the littermates, and seven line 17 transgenic mice and seven wild-type mice from the littermates were used.

Water maze test. Male mice, 60-80 d old, were trained in a circular pool $150 \mathrm{~cm}$ in diameter and $60 \mathrm{~cm}$ in height, containing water at $23 \pm 1^{\circ} \mathrm{C}$. A square Plexiglas platform $\left(12 \mathrm{~cm}^{2}\right)$ was submerged $0.5 \mathrm{~cm}$ below water level. On the first pretraining day mice were placed on the platform for $30 \mathrm{sec}$, and then they were introduced three times into the water $20 \mathrm{~cm}$ from the island so that they could escape to the island from three directions. The mice were left on the island for $30 \mathrm{sec}$ between each trial. In the next days, the mice were given three consecutive trials starting from random starting positions to locate the platform. Each trial lasted up to $90 \mathrm{sec}$. If the mouse did not climb the platform within $90 \mathrm{sec}$, then it was placed on it by hand. After each trial the mice were left on the platform for $30 \mathrm{sec}$. After three days of training the mice did not get any more training, and their memory was tested again $4 \mathrm{~d}$ later. Ten line 9 transgenic mice and 10 wild-type mice from the littermates and seven line 17 transgenic mice and seven wild-type mice from the littermates were used.

\section{RESULTS}

\section{Generation of NR2D transgenic mice}

Immunoblotting shows that NR2 subunits of the NMDA receptor are expressed in the sequence NR2D-NR2B-NR2A during the postnatal development of the hippocampus (Fig. 1). To define the role of NR2D in synaptic function, we created mice overexpressing NR2D in the mature forebrain where endogenous NR2D expression is very low. NR2D cDNA was expressed under the control of the promoter of the CaMKII $\alpha$ gene that supports late onset of transgene expression in a forebrain-specific manner (Mayford et al., 1995). Southern blot analysis showed that six independent lines with different copy numbers of the transgene were generated (Fig. 2A). Northern blot analysis revealed abundant expression of NR2D mRNA in transgenic lines 3, 9, and 17 (Fig. $2 B$ ). These three lines corresponded to the lines determined by Southern blots to have the highest copy number of the transgene. All three lines displayed normal viability and postnatal growth. Two of these lines, 9 and 17, were analyzed in the present study.

In situ hybridization using a probe specific for the transgene revealed selective expression in cortex, hippocampus, and striatum (Fig. 2C). Using a probe recognizing both endogenous and transgenic NR2D transcripts, we observed higher expression of NR2D in the transgenic forebrain. The expression of NR2D in the control forebrain was very low. NR2D protein expression in hippocampus was analyzed by immunoblotting. The level of NR2D protein $\left(M_{\mathrm{r}} 150 \mathrm{kDa}\right)$ detected in extracts from transgenic mice was much higher than the amount of endogenous NR2D protein (Fig. 2D). Upregulation of NR2D protein was observed between 2 and 8 weeks. From 8 to 17 weeks, the protein amount was stable. In the following analysis, we refer to 3-week-old animals as "juvenile" and to 8- to 17-week-old animals as "adult."

Immunoprecipitation experiments were performed to see whether NR2D polypeptide was incorporated into the NMDA receptor complex. An NR1-specific antibody immunoprecipitated NR1 and NR2D polypeptides from a membrane fraction prepared from transgenic mice brains but did not immunoprecipitate 


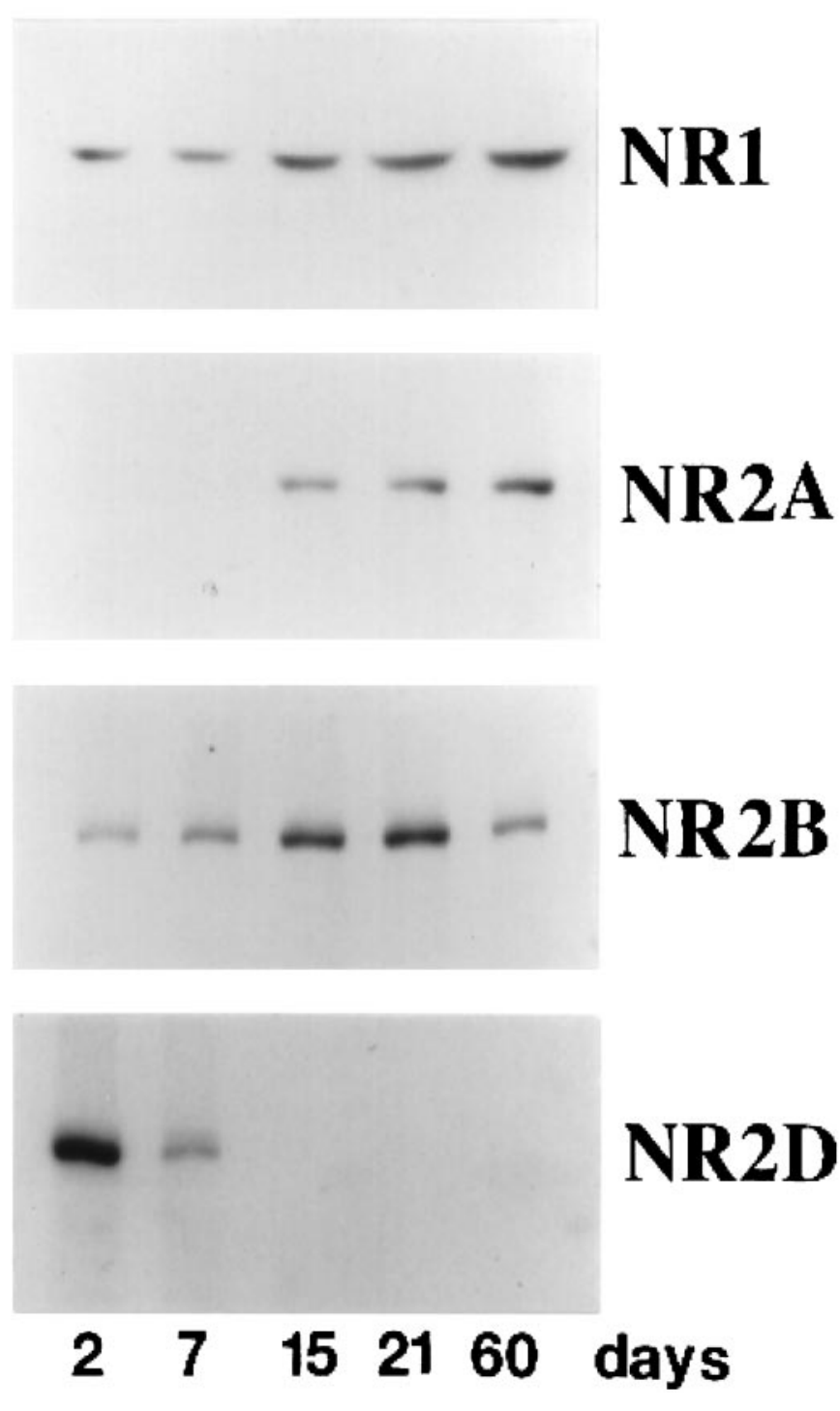

Figure 1. Transition of NMDA receptor subtypes in the postnatal development of the mouse hippocampus. The amount of each NMDA receptor subunit was determined by immunoblotting using antibodies specific to each subunit. Protein samples were prepared from postnatal mouse hippocampi at ages indicated.

AMPA receptor polypeptides (Fig. 2E). An NR1-specific antibody immunoprecipitated only NR1 polypeptide from control brain, consistent with the fact that normally very little NR2D is expressed in the adult forebrain (Fig. 1). These results show the incorporation of the transgene-derived NR2D protein into an NMDA receptor complex.

No gross anatomical abnormality in the transgenic mice was seen in toluidine blue- or anti-calbindin-stained brain sections (Fig. 3A). However, a detailed analysis indicates that the transgenic mouse has an altered dendritic morphology (Cameron et al., 1997). Cytochrome oxidase histochemistry revealed normal architecture of the cortical barrels in the transgenic mice, suggesting again the absence of gross anatomical deficits in the transgenic neocortex (Fig. 3B).

\section{Biochemical characterization of NMDA receptors in NR2D mice}

The expression of other subunits of NMDA receptors in adult transgenic mice was analyzed by Northern blotting (Fig. 4A).
There was no change in the amount of NR1 and NR2A transcripts. In contrast, NR2B transcripts were selectively reduced in transgenic mice. In situ hybridization revealed a widespread reduction of NR2B transcripts in adult cortex, hippocampus, striatum, and thalamus (Fig. $4 B$ ). Immunoblotting showed a reduction of NR2B protein specifically in the adult brain but not in the juvenile brain $[71 \pm 6.1 \%$ of control level for the adult brain $(n=$ $8), 97 \pm 10 \%$ of control level for the juvenile brain $(n=4)$ ] (Fig. $4 C, E)$. We detected no change in the amount of NR1 and NR2A protein in either age group. These results indicate that the NR2B and NR2D proteins are interdependently regulated. A similar reduction of the NR2B subunit was reported in NR1 knock-out mice (Forrest et al., 1994).

\section{Autophosphorylation of CaMKII $\alpha$ in NR2D mice}

It has been shown recently that LTD is selectively modulated in mice expressing constitutively active $\mathrm{CaMKII} \alpha$ protein (Mayford et al., 1995). The level of steady-state $\mathrm{Ca}^{2+}$-independent CaMKII kinase activity is regulated by the autophosphorylation of CaMKII at a single threonine residue (Thr-286) (Miller and Kennedy, 1986; Miller et al., 1988). The amount of CaMKII was not altered by NR2D expression in either age group. We measured directly the amount of Thr-286-phosphorylated CaMKII by using a monoclonal antibody specific for CaMKII that is phosphorylated at Thr-286 (Fig. 4D) (Patton et al., 1993). We observed a $36 \%$ reduction of the amount of autophosphorylated CaMKII in adult hippocampus but no difference in juvenile hippocampus $[64 \pm 5.5 \%$ of control level for the adult brain $(n=8), 103 \pm 8.3 \%$ of control level for the juvenile brain $(n=4)]$ (Fig. 4E).

\section{Electrophysiology in transgenic mice}

The current, amplitude, and kinetics of the transgenic NMDA receptors were evaluated using patch-clamp recordings from visually identified cells in acute hippocampal slices under IR-DIC microscopy. CA1 pyramidal neurons in adult animals (10-12 weeks old) were analyzed when biochemical evidence of transgene expression was most clear. No differences were seen between transgenic $(n=11)$ and wild-type $(n=9)$ cells in capacitance, resistance, and resting membrane potential. However, the NMDA currents evoked by pressure-applied NMDA onto the apical dendrites in the transgenic cells were clearly smaller and slower than those in the wild-type cells. This was true in the presence and absence of external $\mathrm{Mg}^{2+}$, although in $\mathrm{Mg}^{2+}$-free medium the differences were more obvious (Fig. 5A). The skewed kinetics of the transgenic NMDA receptor can also be seen when the current traces were normalized and averaged (Fig. 5B). From these traces the values for time to peak and $\mathrm{T}^{1 / 2}$ decay time for the responses were determined (Fig. 5C).

Synaptic transmission in the hippocampus of adult NR2D mice was analyzed using extracellular recording methods in the in vitro slice preparation. The size and the time course of field EPSP (fEPSP) were measured in the control and NR2D mice as shown in Figure $6 A$. The input-output curve shows that there was no gross difference in the magnitude of synaptic response. There was no difference in the extent of paired-pulse facilitation in normal recording medium (data not shown), which suggested no difference in presynaptic functions. NMDA receptor-mediated EPSPs, estimated by the field response to paired afferent stimulation evoked in the presence of the AMPA receptor antagonist 6,7dinitroquinoxaline-2,3-dione (DNQX), GABA receptor, antagonists (picrotoxin and saclofen), and nominally Mg-free medium, 


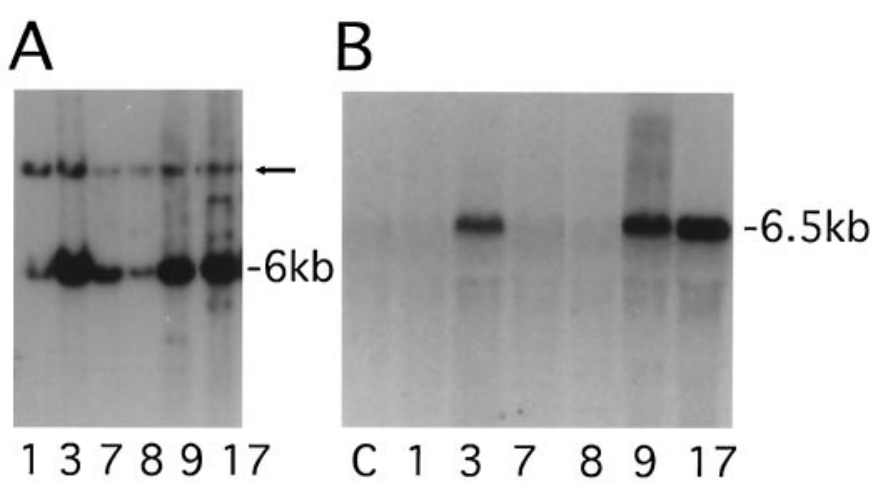

C

Transgenic

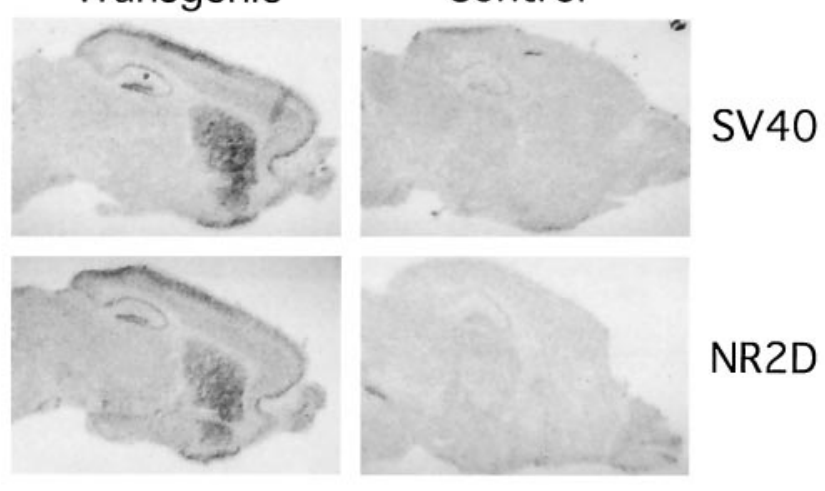

D

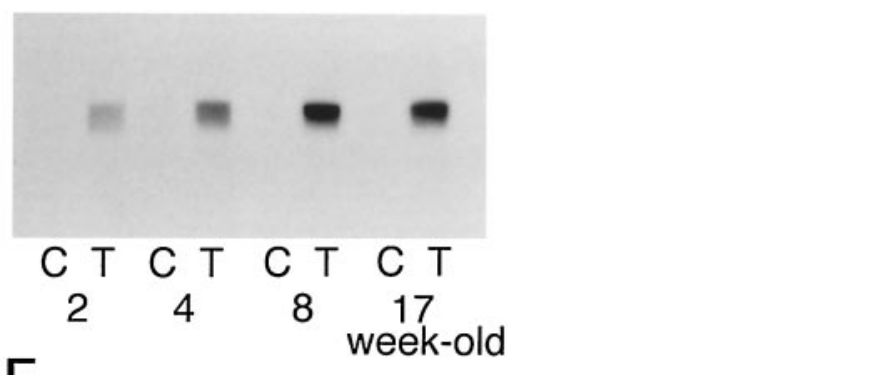

$\mathrm{E}$

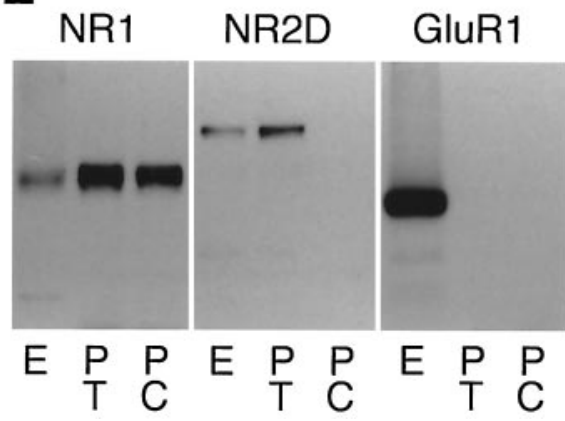

Figure 2. Generation of NR2D transgenic mice. A, Southern blot analysis of the six transgenic lines, $1,3,7,8,9$, and 17 . Successful transmission of the transgene was verified by the presence of a $6 \mathrm{~kb}$ Bam HI fragment. The arrow indicates the position of the endogenous NR2D fragment. $B$, Northern blot analysis with a probe for NR2D transcript. The $6.5 \mathrm{~kb}$ transcript can be identified in lines 3, 9, and 17. Lane C, Transgene negative control. $C$, In situ hybridization of brain sections from transgenic and control mice with a transgene-specific probe ( $S V 40$ polyadenylation signal) and a probe for NR2D. $D$, Immunoblot analysis of the postnatal change of NR2D proteins in control $(C)$ and transgenic $(T)$ mice were significantly smaller in NR2D mice than in controls (Fig. $6 B)$. There was no qualitative difference in the time course of these NMDA receptor-mediated EPSPs. Increases in the duration of the interstimulus interval failed to elicit larger responses in the transgenic mice in contrast to control animals.

The long-term response to tetanic stimulation of the Schaffer collateral CA1 pathway was smaller in adult NR2D mice. The increase in fEPSP slope $30 \mathrm{~min}$ after tetanic stimulation was $54 \pm$ $9 \%$ of the average slope before stimulation in the control and only $18 \pm 8 \%$ in the NR2D line 9 mice (Fig. 6C, 20 slices from eight animals per group). In the traces shown in Figure $6 C$ the slices were exposed to LFS 30 min after tetanus. This LFS caused the expected loss of LTP in the controls but had little effect in the NR2D transgenics, consistent with an impairment in NMDA receptor-dependent LTP. LTP was still present in controls and deficient in NR2D mice for $>60$ min after tetanus (data not shown). Control mice did not show prominent depotentiation at this age, which is consistent with previous reports. Similar LTP defects were obtained with slices from line 17 mice. Because a previous tetanus can alter the properties of a subsequent tetanus, we examined more specifically the ability of the NR2D mice to express LTD. LFS ( $1 \mathrm{~Hz}, 10 \mathrm{~min}$ ) was applied to otherwise naive slices and followed at $20 \mathrm{~min}$ intervals by a $2 \mathrm{~Hz}(10 \mathrm{~min})$ and 5 $\mathrm{Hz}$ (10 min) stimulation. In adult animals, this protocol failed to induce significant LTD in control and transgenics. Responses of slices from transgenic mice were slightly shifted toward potentiation by comparison to that from control mice (Fig. 6E). Thus, overexpression of NR2D in adult hippocampus affects responses to HFS.

\section{LTP and LTD in the juvenile NR2D Mice}

As mentioned above, the amount of NR2D subunit was already elevated, but NR2B was not yet downregulated in the hippocampus of juvenile mice. We therefore tested LTP and LTD expression in juvenile hippocampus. Tetanic stimulation $(100 \mathrm{~Hz}, 1 \mathrm{sec})$ caused a similar long-lasting increase in fEPSP in both control and transgenic mice (Fig. 6D), suggesting that LTP is not sensitive to the expression of NR2D receptor in young animals. LTD was reliably elicited in slices from juvenile mice (Fig. 6F). The response of slices from transgenic mice was systematically shifted toward potentiation in the frequency range of $1-5 \mathrm{~Hz}$. Thus, in juvenile NR2D mice, LTD was blocked without influencing LTP.

\section{NMDA-independent LTP is not impaired in NR2D mice}

It has been proposed recently that NMDA receptor-independent LTP can be evoked by high-frequency $(200 \mathrm{~Hz})$ stimulation (Teyler et al., 1994; Impey et al., 1996). This non-NMDA component of LTP has a typical slow onset and is sensitive to the L-type voltage-gated calcium channel antagonist nifedipine. When isolated in the presence of the NMDA receptor antagonist D-aminophosphonovalerate (D-APV), this non-NMDA potentiation induced by three $200 \mathrm{~Hz}$ tetanic stimuli showed a typical gradual onset that was not different between slices from control and transgenic mice (Fig. $7 A$ ).

hippocampi. Upregulation of NR2D protein level was observed between 2 and 8 weeks. $E$, Immunoprecipitation of NMDA receptor complex with an anti-NR1 antibody. The precipitates were analyzed by immunoblotting with anti-NR1, anti-NR2D, and anti-GluR1 antibodies. E, Extracts from line 9 transgenic forebrain; $P T$, immunoprecipitates from line 9 forebrain; $P C$, immunoprecipitates from control forebrain. 
A

Control
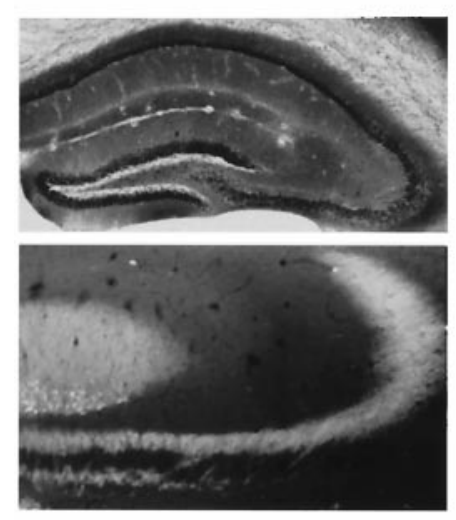

\section{B}

\section{Control}

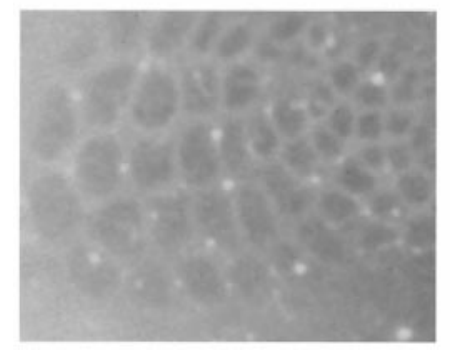

\section{Transgenic}

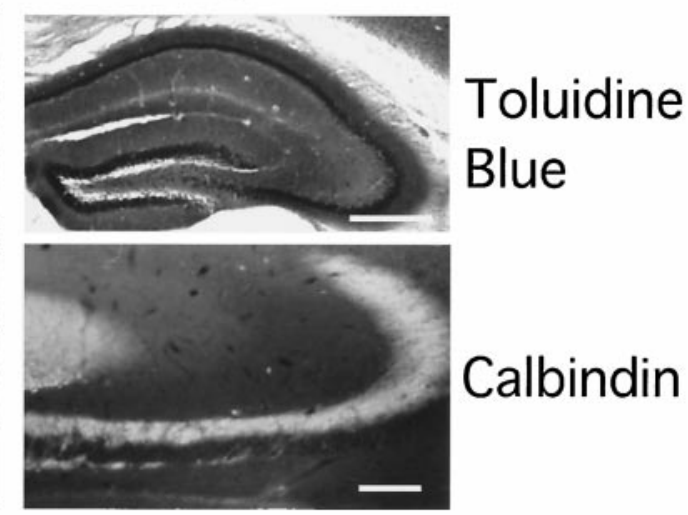

Figure 3. Histochemical and immunohistochemical analysis of NR2D transgenic mice. $A$, Toluidine blue staining of the sections of whole hippocampi and anticalbindin staining of mossy fiber pathway. Scale bars: toluidine blue staining, $500 \mu \mathrm{m}$; calbindin staining, 100 $\mu \mathrm{m}$. $B$, Cytochrome oxidase staining of adult somatosensory cortex. Normal architecture of cortical barrels can be observed in transgenic mice.
To further confirm that NR2D overexpression selectively affects the NMDA-dependent component of LTP, we analyzed LTP in the presence of nifedipine in the adult animals, which showed the greatest differences in NR2D expression and synaptic plasticity. If the effect of NR2D transgene is limited to the NMDA-dependent component, then blockade of voltagesensitive calcium (VSCC) channels would enhance the differential response between control and transgenic mice. We observed enhancement of LTP impairment in the NR2D-overexpressing mice (Fig. 7B). The increase in fEPSP slope $30 \mathrm{~min}$ after tetanic stimulation in the presence of nifedipine was $40.2 \pm 6 \%$ above the average control slope and only $8.1 \pm 6 \%$ above in the transgenic mice (nine slices from three mice in each group). These results confirm that NR2D overexpression specifically diminishes the NMDA-dependent component of LTP and has little effects on NMDA-independent LTP-generating mechanisms.

\section{Transgenic mice behave normally in the Morris water maze}

Because we found impaired LTP and LTD in adult hippocampus, we analyzed behavioral phenotypes of these mice. The adult transgenic mice of both lines 9 and 17 displayed significantly different patterns of behavior from the control mice in an open field. The difference between the genotypes is significant, both in the distance of movement along the perimeter (control, $91.7 \pm 3$; line $9,81 \pm 5$; line 17, $67 \pm 8$ arbitrary units; ANOVA, $F_{(2.47)}=$ $7.95 ; p<0.001)$ and in the number of times they cross the center of the box (control, $16.2 \pm 2.1$; line 9, $7.7 \pm 1.7$; line 17, $8.15 \pm 1.6$ crossings; ANOVA, $\left.F_{(2.47)}=11.28 ; p<0.001\right)$. These results indicate that transgenic mice were less motile and showed less exploratory behavior. These deficits were not caused by motor impairments, because the transgenic mice were at least as good as the controls on a rotary rod (control, $148 \pm 14$; line 9, $197 \pm 17.2$; line $17,163 \pm 13.2 \mathrm{sec}$ ).

The transgenic mice performed indistinguishably from controls in the Morris water maze, where spatial learning and long-term memory were measured (Fig. 8). ANOVA with repeated measures showed no effect of strain, no interaction between the different genotypes and days of training, and no effect on memory after $4 \mathrm{~d}$ without training. The effect of sessions of training was significant $\left(F_{(8.248)}=21.87 ; p<0.001\right)$, indicating that both genotypes reduced their escape latency time in correlation with the amount of training. To verify that the mice learned to locate the platform by using a spatial search strategy, the platform was removed from the maze after the last training day, and the swimming pattern of trained mice was monitored. Both genotypes swam more in the quadrant where the platform was located than in each of the other three quadrants (ANOVA, control, $F_{(3.67)}=7.1 ; p<0.0004$; line $9, F_{(3.39)}=9.04 ; p<0.0002$; line 17, $\left.F_{(3.27)}=5.22 ; p<0.0006\right)$. In summary, no difference between the transgenic mice and controls was seen during either the acquisition or in the quadrant analysis of spatial memory. There was also no difference in the swimming distance between the mice genotypes while performing the last test (control, $236 \pm 18$; line 
A

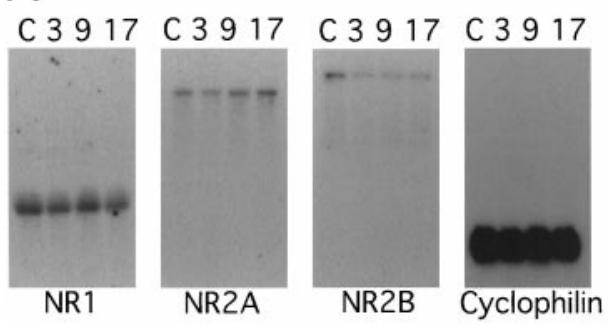

B

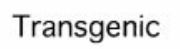

Figure 4. Biochemical analysis of NR2D transgenic mice. $A$, Northern blot analysis with the RNA load controlled by reprobing the membrane with a probe for cyclophilin RNA. NR1 and NR2A levels were unaffected, but all three lines showed reduced amounts of NR2B. B, In situ hybridization of brain with a probe for NR2B. NR2B message is reduced in the transgenic mice forebrain. Scale bar, $2.5 \mathrm{~mm}$. $C$, Immunoblot analysis of extracts from control $(C)$ or transgenic $(T)$ hippocampus at either 3 weeks or 2 months postnatal using antibodies against $N R 1, N R 2 A$, and $N R 2 B . D$, Immunoblot analysis of the amount of $\mathrm{Ca}^{2+}$-independent CaMKII activity using an antibody specific for $\mathrm{CaMKII} \alpha$ that is phosphorylated at Thr-286. Phospho-CaMKII, Thr-286 phosphorylated CaMKII $\alpha . E$, Quantitation of the relative amount of NR2B and autophosphorylated CaM KII $\alpha$ in 3-weekold $(3 w k)$ or 2-month-old $(2 m o)$ transgenic hippocampi. The data were expressed as percent, with the amount in wild-type hippocampi as $100 \%$. Values are mean $\pm \mathrm{SEM} ; n=4$, juvenile brain; $n=8$, adult brain.

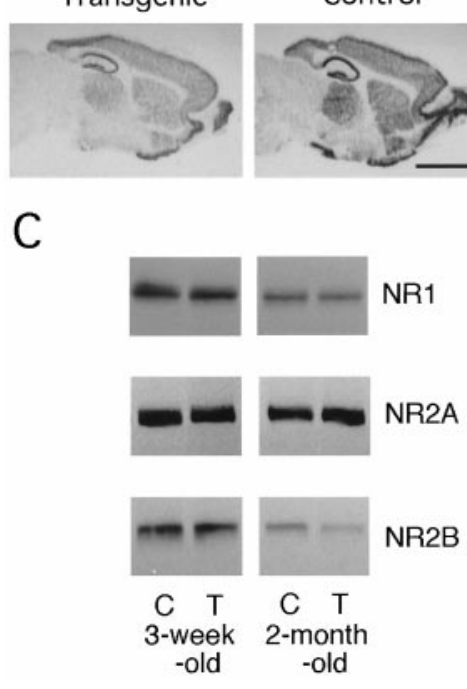

D

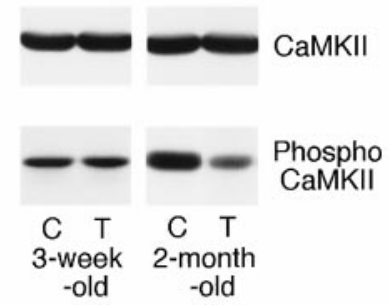

$\mathrm{E}$

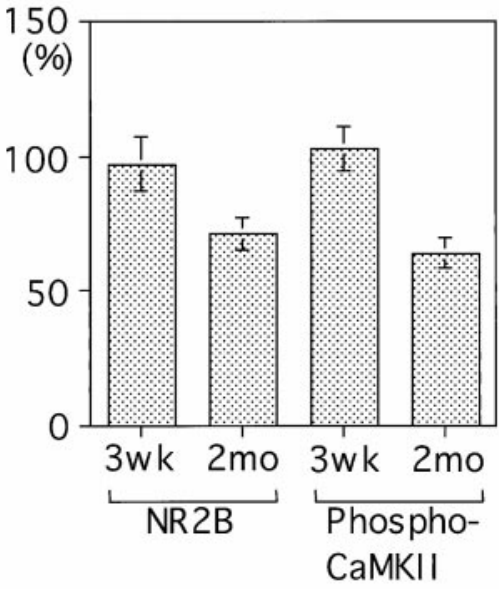

$9,247 \pm 12$; line 17, $211 \pm 17$, arbitrary units), confirming the lack of motor impairment.

\section{DISCUSSION}

To analyze the consequences of modulating the NMDA receptor composition in vivo, we manipulated the NMDA receptor by inserting a predominantly embryonic subunit into the receptor complex in the adult brain by using a late-onset forebrain-specific promoter. The expressed transgenic protein binds to the NR1 subunit of the NMDA receptor. Patch-clamp recordings from acute hippocampal slices of these adult animals showed slower kinetics and a reduction in NMDA currents. We recorded evoked currents in CA1 pyramidal neurons of the adult hippocampus in response to focal application of NMDA. This method allowed us to isolate and accurately compare the responses of the NMDA receptors in transgenic and control neurons. Focal application of NMDA was chosen over synaptic stimulation because it is better suited to analyze the pharmacological properties and kinetics of NMDA receptors. NMDA responses evoked by synaptic stimulation may be contaminated by other components of the synaptic response, which cannot always be completely eliminated, e.g., $\mathrm{GABA}_{\mathrm{A}}, \mathrm{GABA}_{\mathrm{B}}$, and mGluR synaptic responses. Also, the kinetics of the synaptic response is influenced by presynaptic control of transmitter release and reuptake processes, problems not shared by the pressure-applied agonist. Furthermore, synaptic responses are more sensitive to the complexity of space clamp of the cell at remote synaptic sites while focal application of NMDA is applied closer to the soma. One may argue that focal application of NMDA activates extrasynaptic NMDA receptors. How- ever, in the adult rodent most, if not all, functional NMDA receptors appear to be synaptic (Petralia et al., 1994a,b; Fritschy et al., 1998). In our patch-clamp experiments we chose to work only with the adult cells, although it is a more difficult task than working with juveniles, because overexpression of NR2D is most prominent in the adult and is hardly seen in juveniles. These findings are consistent with those shown by Monyer et al. (1994) in heterologous expression system and with Flint et al. (1997) in cortical slices. These data show that the transgenic mice showed changes in synaptic responses in area CA1 of the hippocampus.

Selective impairment of LTD in juvenile mice and impairment of LTP in adult mice suggest that the composition of NMDA receptor subunits regulates both types of synaptic plasticity. A decrease in NMDA-dependent potentiation in adult transgenic mice is further supported by suppressed seizure development in response to kindling in the amygdala (Bengzon et al., 1997). Blockade of NMDA- or VSCC-dependent LTP by pharmacological agents showed selective impairment of the NMDAdependent component of LTP in adult transgenic mice. Therefore, we have provided biophysical evidence that the transgene expression of the NR2D receptor in adult animals caused alterations in the kinetics, amplitude, and $\mathrm{Mg}^{2+}$ sensitivity that are consistent with the alterations observed in synaptic plasticity. In addition, NR2B downregulation probably contributes to the plasticity deficits and emphasizes the importance of future studies on the control of NR2B expression. Downregulation of phosphorylated CaMKII is likely to contribute to the adult phenotype. In contrast, in juveniles LTD can be blocked with no change in the 
A

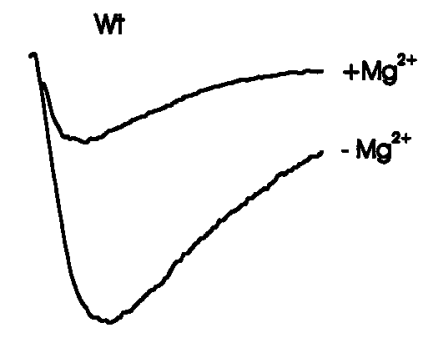

B
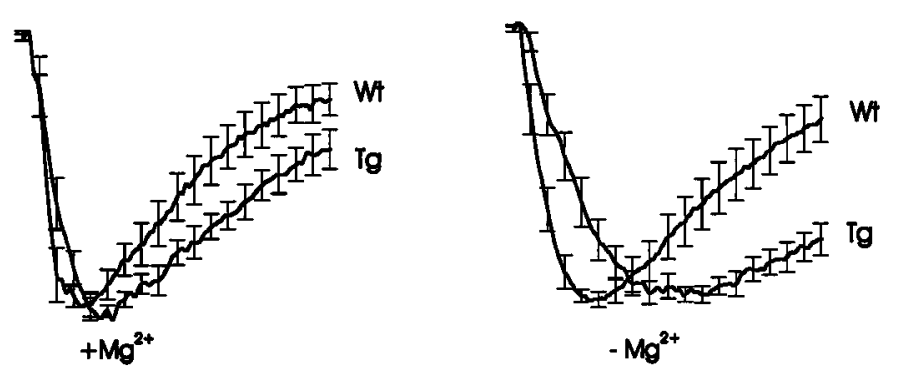

Tg

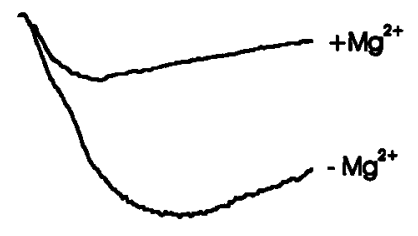

$25 \mathrm{pA}$

$1.0 \mathrm{~s}$

\section{C}
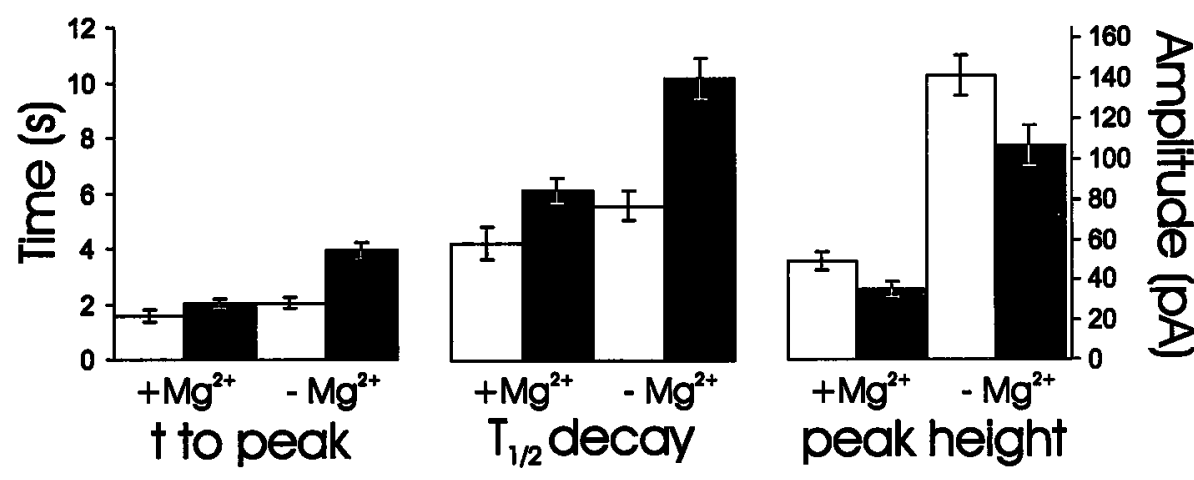

Figure 5. Transgenic mice show NR2D electrophysiological characteristics. Adult NR2D overexpressing mice displayed slower and smaller NMDA currents as recorded by patch-clamp techniques from single CA1 pyramidal neurons. $n=9$, Wild-type mice; $n=11$, transgenic mice. $A$, Averaged traces showing a reduction in peak NMDA current amplitudes in transgenic mice by $30 \%$ in the presence of $\mathrm{Mg}^{2+}$ and by $25 \%$ in the absence of $\mathrm{Mg}^{2+} . B$, Direct comparison of wild type $(W t)$ and transgenic $(T g)$ NMDA responses revealed slower kinetics in the $T g$. This was even more obvious in the absence of external $\mathrm{Mg}^{2+}$. Traces were first normalized according to their peak current amplitude and then averaged together. Peak amplitude was taken as 1.00. $C$, Values measured from $A$ and $B$ represented graphically. Both time to peak and time to decay were prolonged in $\mathrm{Tg}$ in the absence of external $\mathrm{Mg}^{2+}$. Peak amplitude is significantly smaller in $T g$ with and without external $\mathrm{Mg}^{2+}$. In the presence of external $\mathrm{Mg}^{2+}$, the differences were not significant. In $A-C, W t$ is black, and $T g$ is red. Error bars indicate SE. activation of CaMKII. Despite these physiological changes, adult transgenic mice showed normal behavior in the Morris water maze task, suggesting that the full extent of NMDA receptordependent LTP in hippocampal CA1 synapses is not essential for spatial memory.

\section{Modulation of synaptic plasticity by NMDA receptor subunit composition}

In this study we present evidence that the insertion of NR2D subunits into the NMDA receptor complex can selectively modulate the response to LFS toward potentiation. Overexpression of NR2D in juvenile mice did not modulate the expression of other NMDA receptor subunits or the amount of autophosphorylated CaMKII. This suggests that the response in the frequency range of 1-5 Hz in Schaffer collateral CA1 synapses can be modulated by low levels of the NR2D protein through pathways that do not involve the amount of $\mathrm{Ca}^{2+}$-independent CaMKII activity. The validity of the sliding threshold theory should now be explored by analyzing synaptic responses to stimulation at lower frequencies.
Different levels of intracellular $\mathrm{Ca}^{2+}$ induced by either HFS or LFS are thought to activate different signal transduction pathways, inducing either potentiation or depression of synaptic connections (Mulkey and Malenka, 1992). The modification threshold $(\theta)$ is the stimulation frequency beyond which positive synaptic modification is expressed (Bienenstock et al., 1982; Bear et al., 1987). Recent analysis of mice with elevated $\mathrm{Ca}^{2+}$. independent activity of the $\mathrm{CaMKII} \alpha$ protein suggests that the amount of this activity plays a critical role in setting $\theta$ (Mayford et al., 1995). An increase in $\mathrm{Ca}^{2+}$-independent activity of CaMKII led to a shift of $\theta$ to lower frequencies. However, whether $\theta$ is regulated solely by the CaMKII activity is not known. A previous theoretical study showed that $\theta$ might be effectively influenced by several factors, including dendritic spine shape, $\mathrm{Ca}^{2+}$-buffering activity, or properties of NMDA receptors (Gold and Bear, 1994). In adult mice we observed a significant reduction in the amplitude of NMDA receptor-mediated currents in CA1 pyramidal neurons. Both the increase of NR2D and the downregulation of $\mathrm{NR} 2 \mathrm{~B}$ are likely to be responsible for this current reduction. The reduced NMDA receptor-mediated cur- 
A

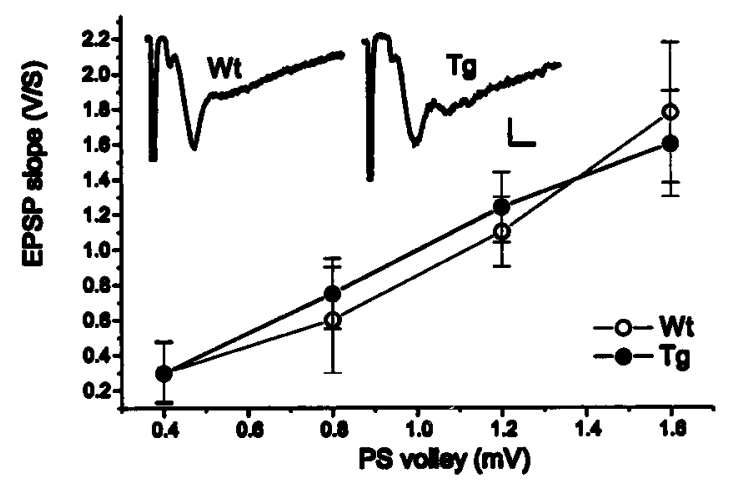

C Adult

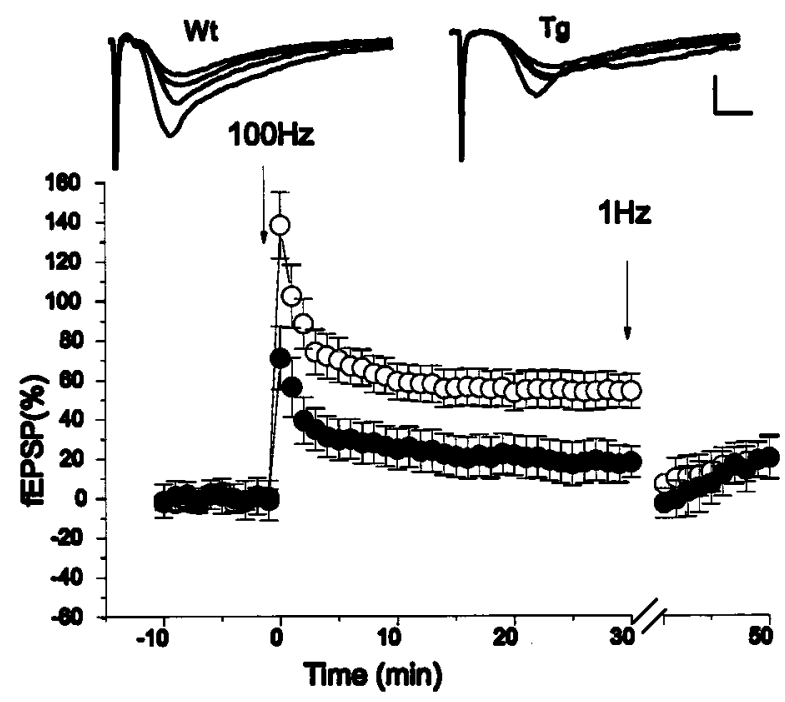

E Adult

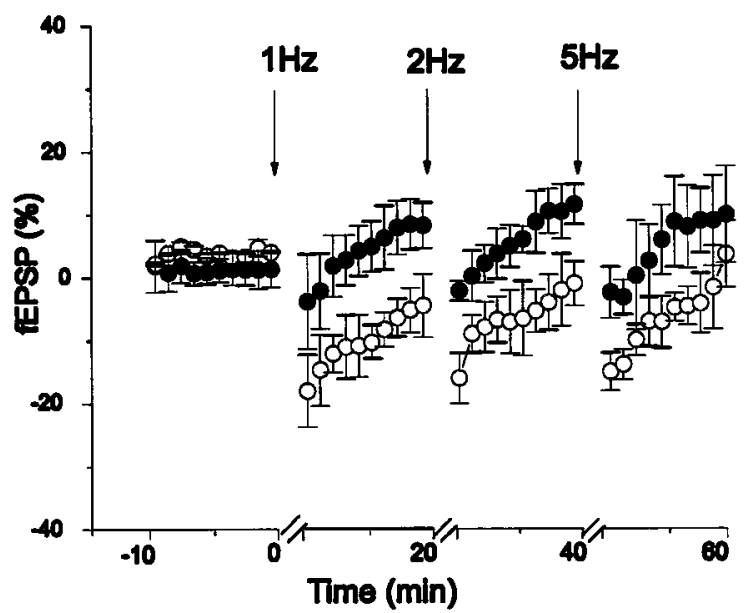

B
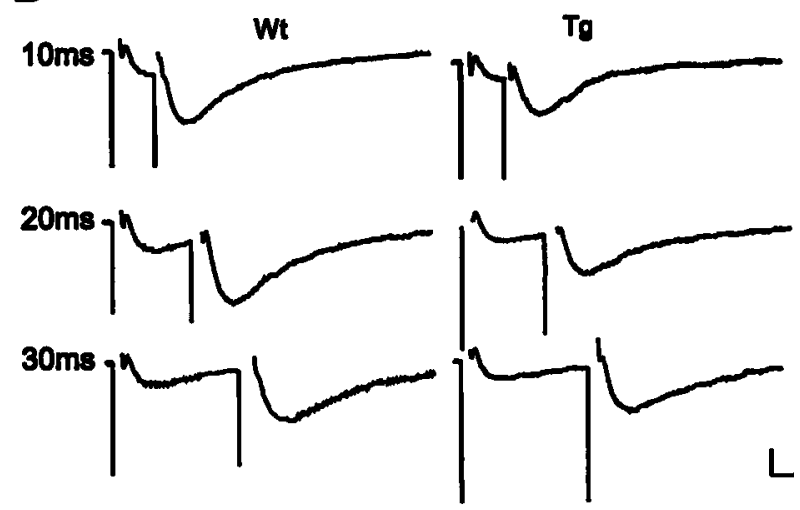

D Young

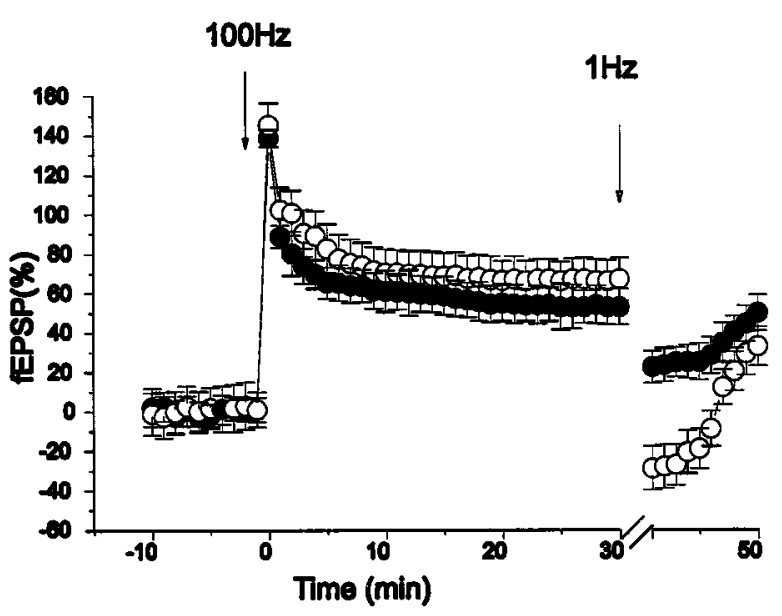

F Young

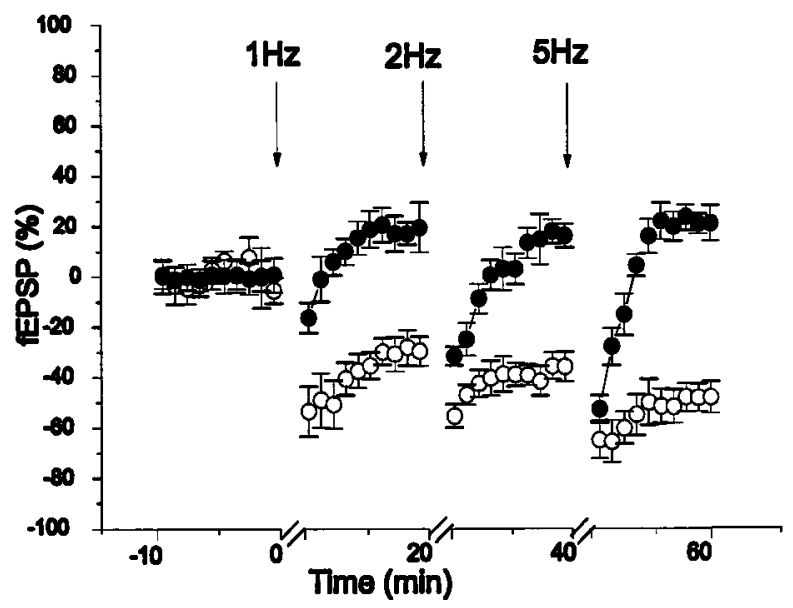

Figure 6. Impaired synaptic plasticity in the hippocampi of NR2D transgenic mice. $A$, Sample traces of fEPSP of normal (black) and transgenic (red) mice recorded in the stratum radiatum of the CA1 region of the hippocampal slice at maximal intensity. Right, Input-output relationship of slices from normal $(n=9)$ and transgenic $(n=9)$ adult animals. Both parameters were similar in both animal groups. The curve was generated by plotting the amplitude of the presynaptic volley versus the amplitude of the fEPSP. $B$, Isolated NMDA receptor-mediated synaptic responses were recorded in a medium containing $10 \mu \mathrm{M}$ DNQX, $50 \mu \mathrm{M}$ picrotoxin, $100 \mu \mathrm{M}$ saclofen, and $0 \mathrm{mM} \mathrm{Mg}{ }^{2+}$. Under these conditions, a paired pulse (Figure legend continues.) 


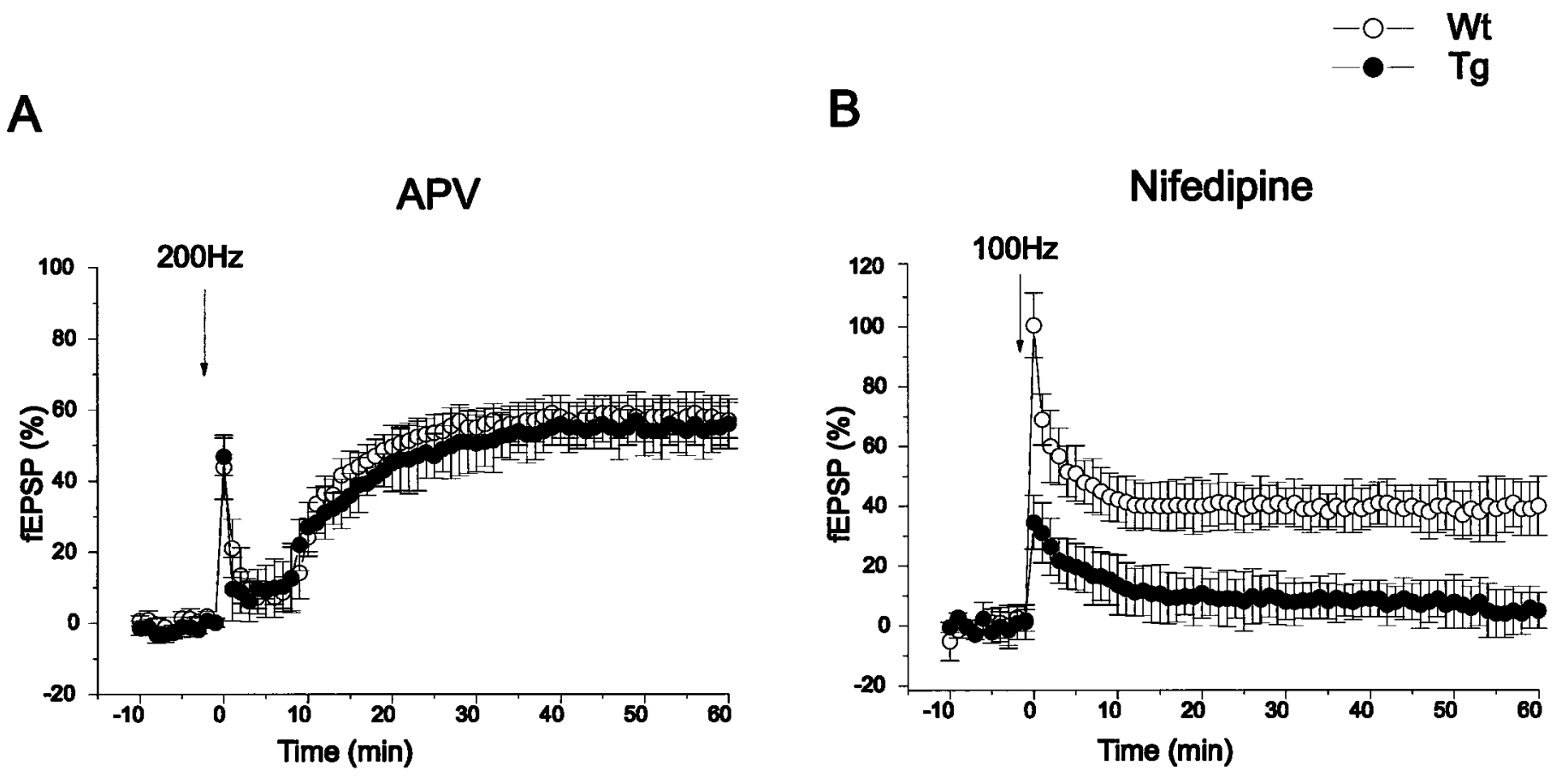

Adult

Adult

Figure 7. Selective impairment of NMDA-dependent component of LTP in NR2D transgenic mice hippocampus. $A$, LTP produced in the presence of the NMDA antagonist D-APV is similar in control and NR2D transgenic mice. Slices were preincubated in $30 \mu \mathrm{M}$ D-APV, and three tetanic stimuli were given at $200 \mathrm{~Hz}$ for $1 \mathrm{sec}$ with an interstimulus interval of $1 \mathrm{sec}$ (arrow). This stimulation pattern produces a slow-onset NMDA-independent potentiation that was similar in the two groups $(n=12$, slices in each group; $n=4$, mice in each group). $B$, NMDA-dependent LTP isolated from the non-NMDA-dependent LTP by preincubation for $10 \mathrm{~min}$ with the VSCC antagonist nifedipine $(30 \mu \mathrm{M})$. Isolation of NMDA-dependent LTP enhanced the difference between control and transgenic mice. Thirty minutes after tetanus LTP magnitude was $40.2 \pm 6 \%$ and $8.1 \pm 6 \%$ in the control and transgenic mice, respectively ( $n=9$, slices in each group; $n=3$, animals in each group).

rent is likely to lower the $\mathrm{Ca}^{2+}$ level in the postsynaptic site, leading to the observed downregulation of CaMKII activity. At a qualitative level, a reduced NMDA receptor-mediated current would be sufficient to account for the altered synaptic physiology reported.

The data presented here show that developmental changes in the NMDA receptor composition can regulate synaptic properties. LTP can be induced as early as postnatal day 2 in the rat hippocampus (Durand et al., 1996). The appearance of this early form of LTP coincides with the disappearance of NR2D subunit in the hippocampus. The transition of the receptor composition from the NR2B-dominant form to the NR2A-dominant form takes place around postnatal days 14-21. Interestingly, this time course again corresponds to the gradual loss of LTD (Dudek and Bear, 1993). Activity-dependent modification of synaptic effectiveness has been proposed as a critical step in the development of synaptic connectivity (Kirkwood et al., 1996; Stevens, 1996). The results reported here suggest that the NR2 subunit composition of NMDA receptors is a critical feature of the mechanism that regulates the developmental steps in synaptic plasticity.

$\longleftarrow$

stimulation was required to elicit a slow fEPSP that is mediated by NMDA receptors [interstimulus interval (ISI) of 10, 20, and 30 msec]. The traces are averages of six separate slices from two animals in each group. The fEPSP of transgenic mice was smaller in magnitude than the fEPSP of normal mice. Using a $10 \mathrm{msec}$ ISI, the fEPSP average was $2.7 \pm 0.3 \mathrm{mV}$ in transgenic mice and $3.7 \pm 0.2 \mathrm{mV}$ in the controls. At $20 \mathrm{msec}$, the fEPSP average was $2.8 \pm 0.4 \mathrm{mV}$ in transgenic mice and $4.8 \pm 0.3 \mathrm{mV}$ in the controls. At $30 \mathrm{msec}$, the fEPSP average was $2.9 \pm 0.3 \mathrm{mV}$ in transgenic mice and $3.8 \pm$ $0.4 \mathrm{mV}$ in the controls. All of these differences were significant $(p<0.001, t$ test). Before the addition of the blockers, the input-output relationship was found to be similar in both animal groups; the maximal amplitude of the fEPSP in normal medium at $10 \mathrm{msec}$ ISI was $4.86 \pm 0.48 \mathrm{mV}$ and $4.90 \pm 0.40$ $\mathrm{mV}$ in transgenic mice. Calibration: $2 \mathrm{msec}, 2 \mathrm{mV}$ for top 2 traces; $6 \mathrm{msec}, 2 \mathrm{mV}$ for bottom 2 traces). $C$, In adult (2-month-old) line 9 transgenic mice, LTP evoked by a single $100 \mathrm{~Hz}$ tetanic stimulation for $1 \mathrm{sec}$ amounted to a $18 \pm 8 \%$ potentiation above basal levels $($ filled circles; $n=20$, slices; $n=$ 8 , mice) compared with a $54 \pm 9 \%$ in the control slices (open circles; $n=20$, slices; $n=8$, mice). Thirty minutes after the tetanic stimulation, a train of stimuli at $1 \mathrm{~Hz}$ was applied for $10 \mathrm{~min}$, resulting in fEPSP values of $6.6 \pm 8 \%$ in the controls and $3 \pm 8 \%$ in the transgenic mice. The transgenic mice show no significant change in synaptic response. The insets are superimposed sample traces of normal (left) and transgenic (right) animals during the course of the LTP experiments: baseline, post-tetanic potentiation, and LTP. $D$, In juvenile (3-week-old) line 9 hippocampus, the magnitude of LTP 30 min after tetanus is similar to that of controls $(67 \pm 10 \%$ and $53 \pm 9 \%$ in control and transgenic mice, respectively; $n=20$, slices in each group; $n=$ 7 , mice in each group). A transient depotentiation was seen in the control mice with a less pronounced effect in the transgenic animals $(-29 \pm 11 \%$ and $22 \pm 8 \%$ in control and transgenic mice, respectively). $E$, LTD in adult normal and transgenic mice. The depressing stimulus trains are 1,2 , and $5 \mathrm{~Hz}$ applied at arrows as indicated ( $n=7$, slices in each group; $n=6$, mice in each group). $F$, Long-term depression of fEPSPs in juvenile (3-week-old) line 9 transgenic mice is impaired compared with the wild-type controls. The depressing stimulus trains are 1,2 , and $5 \mathrm{~Hz}$ applied at arrows as indicated. ( $n=$ 7, slices in each group; $n=3$, mice in each group). 
A.

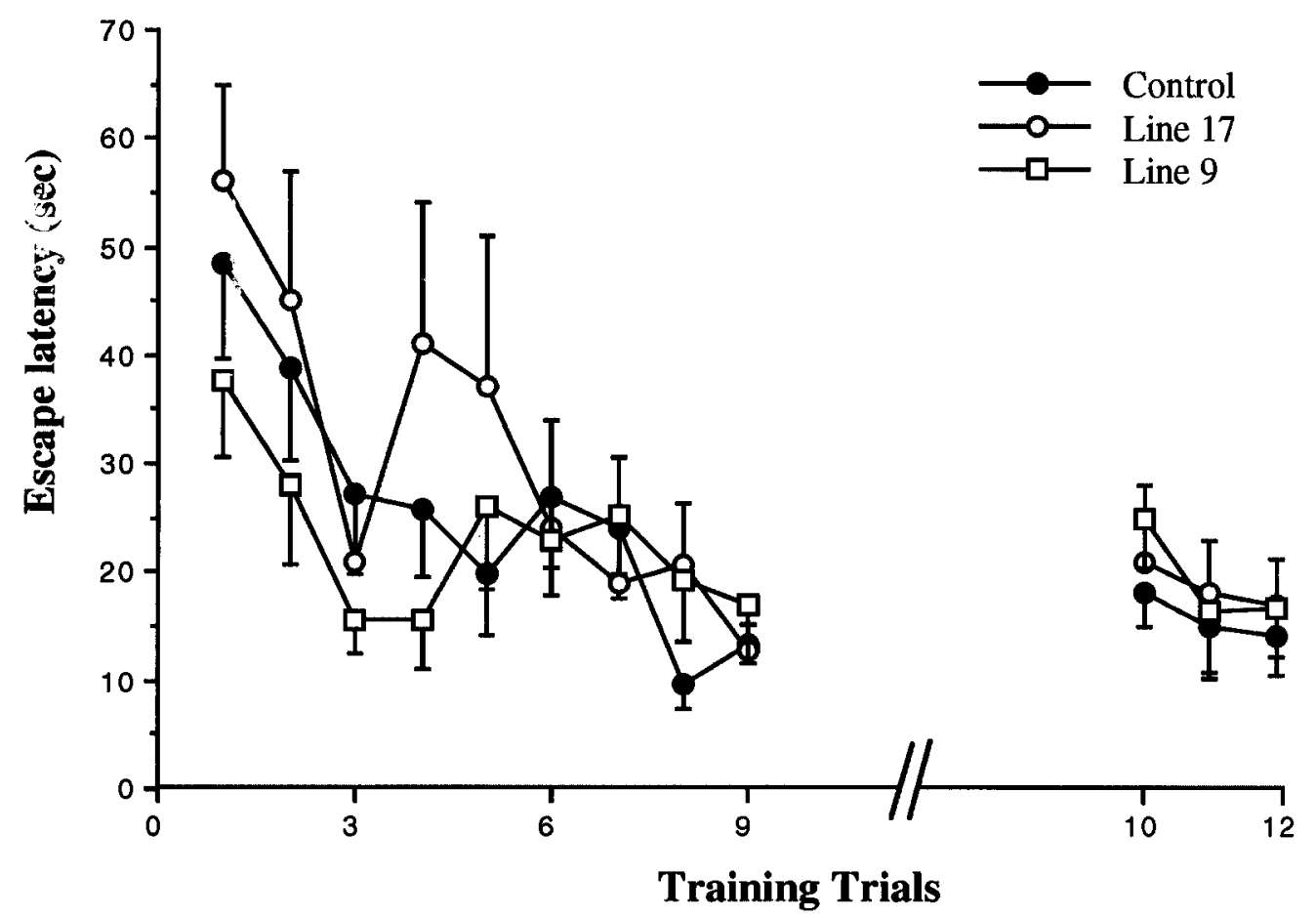

B.

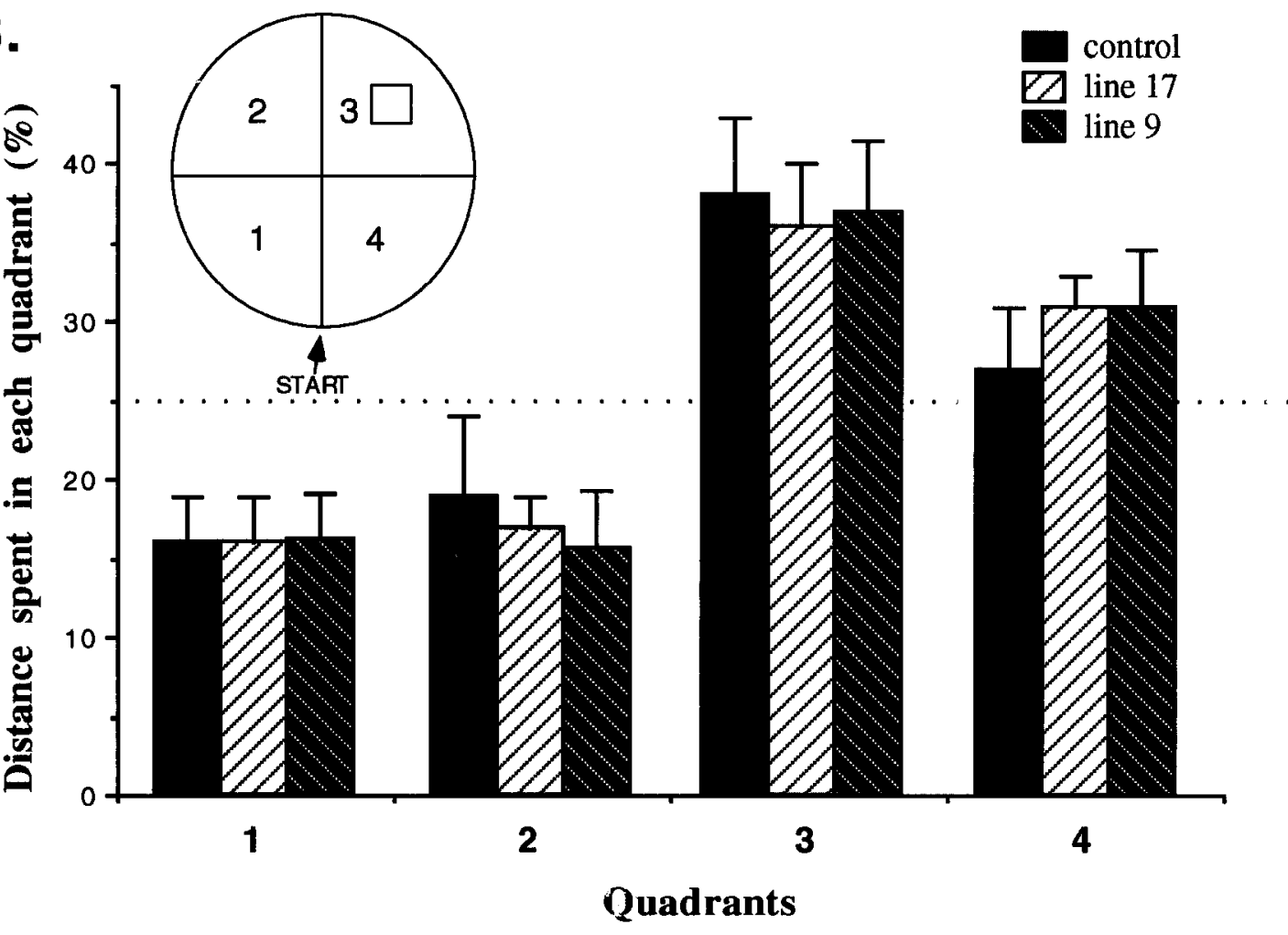

Figure 8. Performance of mice in water maze learning task. $A$, Escape latency to find a submerged island. Mice were trained for three sessions each day on 3 consecutive days. Then they did not get any additional training for $4 \mathrm{~d}$ and were tested again on the fifth day. $B$, A comparison of the time trained mice spent in each quadrant of a water maze. This experiment was performed $24 \mathrm{hr}$ after the last training day. The location of the island during training was in quadrant three and was removed in the last experimental day to verify spatial learning. START is the point where the mice were introduced into the maze in the quadrant test. Values are mean \pm SEM; $n=17$, control; $n=10$, line 9; $n=7$, line 17. 


\section{Relationship between LTP and spatial memory}

The NR2D transgenic mice showed greatly diminished CA1 hippocampal LTP but normal behavior in the water maze test. A similar dissociation between LTP and cognitive behavior has been reported for the mossy fiber CA3 LTP in protein kinase A knock-out mice (Huang et al., 1995). These results suggest that LTP is not essential for spatial memory, but the possibility has been proposed that information for spatial learning can reach the CA1 region without relaying to the dentate gyrus (Huang et al., 1995). However, our results show that the full extent of CA1 LTP is not essential for spatial learning.

Mice lacking NMDA receptor function specifically in the area CA1 of the hippocampus clearly show a complete loss of both LTP and spatial learning (Tsien et al., 1996). A major difference between CaMKII NR2D mice and CA1-specific NR1 knock-out mice is that the latter showed greatly diminished short-term potentiation and complete loss of LTP (Tsien et al., 1996, their Fig. 6), whereas the former had a certain amount of short-term potentiation and a residual amount of LTP (Fig. 6 of this paper). A similar dissociation between LTP impairment in the CA1 and behavioral deficit was reported in PKC- $\gamma$ knock-out mice (Abeliovich, et al., 1993a,b). These results are consistent with the view that CA1 NMDA receptors are essential for the acquisition of spatial memory, whereas the full extent of LTP is not required.

The first indication of the relationship between NMDAdependent LTP and spatial learning was obtained from studies using local administration of NMDA antagonists and subsequent analysis with the Morris water maze test (Morris et al., 1986). However, recent studies have shown that the antagonist-induced block in learning can be prevented by pretraining rats on general task requirements (Bannerman et al., 1995, Saucier and Cain, 1995). These experiments suggest that a pharmacological block of NMDA-dependent LTP does not necessarily prevent the central component of water maze learning. It is not clear whether NMDA receptor antagonist blocks the whole functional repertoire of NMDA receptors or selectively blocks NMDAdependent LTP in these experiments. By generating mouse models with different degrees of NMDA receptor impairment, it will be possible to systematically analyze the relationship between receptor function, synaptic plasticity, and cognitive behavior.

If one accepts the dissociation between LTP and spatial learning, then our results raise the interesting question of which other synaptic processes might correlate with learning. Potentiation in the presence of the VSCC blocker nifedipine provides the clearest evidence for a specific deficit in the NMDA receptor-dependent component of synaptic plasticity in NR2D mice. It has been proposed recently that the protein kinase A- and protein synthesis-dependent late-phase LTP (L-LTP) is a consequence of VSCC activation (Impey et al., 1996). In contrast, decremental LTP (D-LTP) is dependent on the activation of NMDA receptors but lasts only for 1-3 hr. Consistent with this idea, mice with altered cAMP response element-binding protein expression have normal D-LTP but are defective in L-LTP and show impaired spatial learning (Bourtchuladze et al., 1994). These observations suggest that VSCC-dependent long-lasting LTP that is preserved in NR2D mice may be correlated with spatial memory tested in the water maze task. Because either nominal or saturated LTP in the transgenic animals may be sufficient to support water maze learning, the use of other LTP induction protocols should be considered in the future. Other behavioral paradigms such as fear conditioning and anatomical substrates, e.g., the amygdala (Bram- billa et al., 1997), may be more sensitive to the type of synaptic deficits induced by the NR2D transgene.

\section{REFERENCES}

Abeliovich A, Chen C, Goda Y, Silva AJ, Stevens CF, Tonegawa S (1993a) Modified hippocampal long-term potentiation in $\mathrm{PKC} \gamma$ mutant mice. Cell 75:1253-1262.

Abeliovich A, Paylor R, Chen C, Kim JJ, Wehner JM, Tonegawa S (1993b) PKC $\gamma$ mutant mice exhibit mild deficits in spatial and contextual learning. Cell 75:1263-1271.

Bannerman DM, Good MA, Butcher SP, Ramsay M, Morris RGM (1995) Distinct components of spatial learning revealed by prior training and NMDA receptor blockade. Nature 378:182-186.

Bear MF, Cooper LN, Ebner FF (1987) A physiological basis for a theory of synaptic modification. Science 237:42-48.

Bengzon J, Okabe S, McKay RDG, Lindvall O (1997) Suppressed kindling epileptogenesis in transgenic mice expressing NMDA receptor subunit NR2D in forebrain neurons. Soc Neurosci Abstr 23:2160.

Bienenstock EL, Cooper LN, Munro PW (1982) Theory for the development of neuron selectivity: orientation specificity and binocular interaction in visual cortex. J Neurosci 2:32-48.

Bourtchuladze R, Frenguelli B, Blendy J, Cioffi D, Schutz G, Silva AJ (1994) Deficient long-term memory in mice with a targeted mutation of the cAMP-responsive element-binding protein. Cell 79:59-68.

Brahos JI, Wenthold RJ (1996) Relationship between N-methyl-Daspartate receptor NR1 splice variants and NR2 subunits. J Biol Chem 271:15669-15674.

Brambilla R, Gnesutta N, Minichiello L, White G, Roylance AJ, Herron CE, Ramsey M, Wolfer DP, Cestari V, Rossi-Arnaud C, Grant SGN Chapman PF, Lipp HP, Sturani E, Klein R (1997) A role for the Ras signalling pathway in synaptic transmission and long-term memory. Nature 390:281-286.

Cameron HA, Okabe S, McKay RDG (1997) Overexpression of the NMDA subunit NR2D alters CA1 pyramidal cell morphology. Soc Neurosci Abstr 23:1752.

Carmignoto G, Vicini S (1992) Activity-dependent decrease in NMDA receptor responses during development of the visual cortex. Science 258:1007-1011.

Collingridge GL, Kehl SL, McLennan H (1983) Excitatory amino acids in synaptic transmission in the Schaffer collateral-commissural pathway of the rat hippocampus. J Physiol (Lond) 334:33-40.

Dudek SM, Bear MF (1992) Homosynaptic long-term depression in area CA1 of hippocampus and the effects of NMDA receptor blockade. Proc Natl Acad Sci USA 89:4363-4367.

Dudek SM, Bear MF (1993) Bidirectional long-term modification of synaptic effectiveness in the adult and immature hippocampus. J Neurosci 13:2910-2918.

Durand GM, Kovalchuk Y, Konnerth A (1996) Long-term potentiation and functional synapse induction in developing hippocampus. Nature 381:71-75.

Flint AC, Maisch US, Weishaupt JH, Kriegstein AR, Monyer H (1997) NR2A subunit expression shortens NMDA receptor synaptic currents in developing neocortex. J Neurosci 17:2469-2476.

Forrest D, Yuzaki M, Soares HD, Ng L, Luk DC, Sheng M, Stewart CL, Morgan JI, Connor JA, Curran T (1994) Targeted disruption of NMDA receptor 1 gene abolishes NMDA response and results in neonatal death. Neuron 13:325-338.

Fritschy JM, Weinmann O, Wenzel A, Benke D (1998) Synapse-specific localization of NMDA and GABA(A) receptor subunits revealed by antigen-retrieval immunohistochemistry. J Comp Neurol 390:194-210.

Gold JI, Bear MF (1994) A model of dendritic spine $\mathrm{Ca}^{++}$concentration exploring possible bases for a sliding synaptic modification threshold. Proc Natl Acad Sci USA 91:3941-3945.

Huang Y-Y, Kandel ER, Varshavsky L, Brandon EP, Qi M, Idzerda RL, McKnight GS, Bourtchuladze R (1995) A genetic test of the effects of mutations in PKA on mossy fiber LTP and its relation to spatial and contextual learning. Cell 83:1211-1222.

Impey S, Mark M, Villacres EC, Poser S, Chavkin C, Storm DR (1996) Induction of CRE-mediated gene expression by stimuli that generate long-lasting LTP in area CA1 of the hippocampus. Neuron 16:973-982.

Kirkwood A, Rioult MG, Bear MF (1996) Experience-dependent modification of synaptic plasticity in visual cortex. Nature 381:526-528.

Kutsuwada T, Kashiwabuchi N, Mori H, Sakimura K, Kushiya E, Arai K, Meguro H, Masaki H, Kumanishi T, Arakawa M, Mishina M (1992) Molecular diversity of the NMDA receptor channel. Nature 358:36-41. 
Mayford M, Wang J, Kandel ER, O'Dell TJ (1995) CaMKII regulates the frequency-response function of hippocampal synapses for the production of both LTD and LTP. Cell 81:891-904.

Miller SG, Kennedy MB (1986) Regulation of brain type II $\mathrm{Ca}^{++}$/ calmodulin-dependent protein kinase by autophosphorylation: A $\mathrm{Ca}^{++}$-triggered molecular switch. Cell 44:861-870.

Miller SG, Patton BL, Kennedy MB (1988) Sequences of autophosphorylation sites in neuronal type II $\mathrm{CaM}$ kinase that control $\mathrm{Ca}^{++}$ independent activity. Neuron 1:593-604.

Monyer H, Burnashev N, Laurie DJ, Sakmann B, Seeburg PH (1994) Developmental and regional expression in the rat brain and functional properties of four NMDA receptors. Neuron 12:529-540.

Moriyoshi K, Masu M, Ishii T, Shigemoto R, Mizuno N, Nakanishi S (1991) Molecular cloning and characterization of the rat NMDA receptor. Nature 354:31-37.

Morris RG, Anderson E, Lynch GS, Baudry M (1986) Selective impairment of learning and blockade of long-term potentiation by an $N$-methyl-D-aspartate receptor antagonist, AP5. Nature 319:774-776.

Mulkey RM, Malenka RC (1992) Mechanisms underlying induction of homosynaptic long-term depression in area CA1 of the hippocampus. Neuron 9:967-975.

Patton BL, Molley SS, Kennedy MB (1993) Autophosphorylation of type II CaM kinase in hippocampal neurons: localization of phosphoand dephosphokinase with complementary phosphorylation sitespecific antibodies. Mol Biol Cell 4:159-172.

Petralia RS, Yokotani N, Wenthold RJ (1994a) Light and electron mi- croscope distribution of the NMDA receptor subunit NMDAR1 in the rat nervous system using a selective anti-peptide antibody. J Neurosci 14:667-696.

Petralia RS, Wang YX, Wenthold RJ (1994b) The NMDA receptor subunits NR2A and NR2B show histological and ultrastructural localization patterns similar to those of NR1. J Neurosci 14:6102-6120.

Saucier D, Cain DP (1995) Spatial learning without NMDA receptordependent long-term potentiation. Nature 378:186-189.

Sheng M, Cummings J, Roldman LA, Jan YN, Jan LY (1994) Changing subunit composition of heteromeric NMDA receptors during development of rat cortex. Nature 368:144-147.

Stevens CF (1996) Strengths and weaknesses in memory. Nature 381:471-472.

Stuart GJ, Dodt H-U, Sakmann B (1993) Patch clamp recordings from the soma and dendrites of neurons in brain slices using infrared video microscopy. Pflügers Arch 423:511-518.

Teyler TJ, Cavus I, Coussens C, Discenna P, Grover L, Lee YP, Little Z (1994) Multideterminant role of calcium in hippocampal synaptic plasticity. Hippocampus 4:623-634.

Tsien JZ, Huerta PT, Tonegawa S (1996) The essential role of hippocampal CA1 NMDA-receptor dependent synaptic plasticity in spatial memory. Cell 87:1327-1328.

Watanabe M, Mishina M, Inoue Y (1992) Developmental changes in distribution of NMDA receptor channel subunit mRNAs. NeuroReport 3:1138-1140. 